\title{
Dermatological Toxicity in Women With Breast Cancer Undergoing Chemotherapy Treatment
}

\author{
Thais de Oliveira Gozzo ${ }^{1}$ \\ Marislei Sanches Panobianco ${ }^{1}$ \\ Maria José Clapis² \\ Ana Maria de Almeida ${ }^{2}$
}

This study aimed to analyze the occurrence of skin toxicity caused by drugs used in the protocol of neoadjuvant and adjuvant chemotherapy among women with breast cancer. Patient records of 72 women who were subject to this therapy between 2003 and 2006 were assessed. Of the 558 cycles of chemotherapy, 152 adverse events were registered. There were 37 registrations of dermatological toxicity, of those, 20 were extravasations that affected 17 women. Nine reports of hardened local injury, local fibrosis, pain, and hyperemia were registered during neoadjuvancy. In adjuvancy, among the 11 extravasations registered there were reports of hardened local injury, fibrosis and local pain. Lack of follow-up records for both periods was observed. Registration of the events and reports by the nursing team are essential to monitor the sites of venous puncture during the chemotherapy treatment, besides measuring and making a photographic record of the site.

Descriptors: Drug Therapy; Breast Neoplasms; Extravasation of Diagnostic and Therapeutic Materials; Nursing.

\footnotetext{
Escola de Enfermagem de Ribeirão Preto, Universidade de São Paulo, WHO Collaborating Centre for Nursing Research Development, SP, Brazil:

${ }^{1}$ RN, Ph.D. in Nursing, Professor. Email: thaisog@eerp.usp.br, email: marislei@eerp.usp.br.

${ }^{2}$ RN, Ph.D. in Nursing, Associate Professor. Email: maclapis@eerp.usp.br, email: amalmeid@eerp.usp.br.
}

Corresponding Author:

Thais de Oliveira Gozzo

Universidade de São Paulo. Escola de Enfermagem de Ribeirão Preto

Av. Bandeirantes, 3900

Bairro Monte Alegre

CEP: 14040-902 Ribeirão Preto, SP, Brasil

E-mail: thaisog@eerp.usp.br 


\title{
Toxicidade dermatológica em mulheres com câncer de mama submetidas à quimioterapia
}

O objetivo deste estudo foi analisar a ocorrência de toxicidade dermatológica, provocada por drogas utilizadas no protocolo de quimioterapia neoadjuvante e adjuvante, entre mulheres com câncer de mama. Foram avaliados 72 prontuários de mulheres submetidas a essa terapia, entre 2003 e 2006. De 558 ciclos de quimioterapia, foram registrados 152 eventos adversos, 37 de toxicidade dermatológica, e, desses, 20 eram ocorrências de extravasamento em um total de 17 mulheres. Observou-se nove ocorrências na neoadjuvância com registros nos prontuários de lesão endurecida no local, fibrose local, dor e hiperemia. Na adjuvância, dos 11 extravasamentos registrados, destacam-se lesão endurecida no local, fibrose e dor local. Houve falta de registro de seguimento e avaliação dos eventos adversos para os dois períodos. O registro das intercorrências pela equipe de enfermagem é essencial para o acompanhamento dos sítios de punções venosas, utilizados durante o tratamento quimioterápico, além da mensuração e registro fotográfico do local.

Descritores: Quimioterapia; Neoplasias da Mama; Extravasamento de Materiais Terapêuticos e Diagnósticos; Enfermagem.

\section{Toxicidad dermatológica en mujeres con cáncer de mama sometidas a quimioterapia}

\begin{abstract}
El objetivo de este estudio fue analizar la ocurrencia de toxicidad dermatológica provocada por drogas utilizadas en el protocolo de quimioterapia neoadyuvante y adyuvante entre mujeres con cáncer de mama. Fueron evaluadas 72 fichas de mujeres sometidas a esta terapia de 2003 a 2006. De 558 ciclos de quimioterapia, fueron registrados 152 eventos adversos, 37 de toxicidad dermatológica; de estos, 20 fueron ocurrencias de extravasación de líquido ocurridos en un 17 mujeres. Se observó 9 ocurrencias en la quimioterapia neoadyuvante con registros en las fichas de lesión endurecida en el local, fibrosis local, dolor e hiperemia. En la quimioterapia adyuvante, de las 11 extravasaciones registradas, se destacan lesión endurecida en el local, fibrosis y dolor local. Hubo falta de registro de seguimiento y evaluación de los eventos adversos para los dos períodos. El registro de las interocurrencias por el equipo de enfermería es esencial para el acompañamiento de los sitios de punciones venosas utilizados durante el tratamiento de quimioterapia, además de mensuración y registro fotográfico del local.
\end{abstract}

Descriptores: Quimioterapia; Neoplasias de la Mama; Extravasación de Materiales Terapéuticos y Diagnósticos; Enfermería.

\section{Introduction}

Antineoplastic chemotherapy or use of chemical agents, singly or in combination, has been one of the principle modes of treatment for malignant tumors. Nonetheless, the indiscriminate attack promoted by chemotherapeutic agents on cancer or normal cells generates undesirable effects, known and feared by individuals who need this type of treatment ${ }^{(1)}$. These effects are called adverse events, and include any unfavorable symptom, sign or disease, including abnormal laboratory findings, temporarily associated with the use of treatment or medical procedure ${ }^{(2)}$.

The adverse effects of chemotherapeutic drugs have varying frequencies and intensities, according to the drugs used, and can be divided into non-hematological, which include gastrointestinal, pulmonary, cardiac, hepatic, neurological, renal, bladder and dermatological 
toxicities, reproductive disorders, metabolic alterations, allergic reactions and fatigue; and hematological, which include leukopenia, anemia, thrombocytopenia and febrile neutropenia(1).

The adverse dermatological events occur in the tissue around the area of drug application. This group includes changes such as: phlebitis, rash, pain, erythema and tissue necrosis secondary to extravasation of vesicant drugs out of the venous bed. They may also occur systemically, alopecia being the most common, followed by less common changes such as erythema, urticaria, photosensitivity, hyperpigmentation and changes to the nails ${ }^{(1)}$.

In addition to these adverse events, extravasation may occur in the administration of the chemotherapeutics. This is a term used to describe the unintentional administration of vesicant solution or medication into areas outside of the venous system ${ }^{(3-4)}$. The incidence of extravasation of vesicant drugs, published in the scientific literature, is 0.01 to $6.5 \%$, but there is a possibility of underreporting of cases $^{(1,3)}$. Morbidity is related to the amount of drug extravasated, its concentration, the location of extravasation, the type of device used in venous access, the conditions of health of the patient and the interval between the occurrence of the event and its recognition and treatment ${ }^{(3-4)}$.

The extravasation of vesicant drugs causes severe irritation with vesicle formation and tissue destruction(5), which may cause functional damage, neurological alterations, alterations in body image and, principally, the patient's loss of trust in the health professional(3).

There are irritant drugs that, in this case, provoke cutaneous reactions of lesser intensity, such as pain and burning, but even when infused properly can cause pain and an inflammatory reaction along the blood vessel used for the infusion ${ }^{(1)}$.

Also in relation to the extravasation of vesicant drugs, for each one there are procedures and antidotes that can be administered immediately after the occurrence of extravasation, through the same needle, subcutaneously around the site of extravasation, after aspiration of the highest quantity possible of the infiltrated drug.

The objective of the application of the antidotes is to limit the local inflammatory process, inactivate and remove the remaining drug and its use should be prescribed by a doctor or be defined by protocol approved by the institution ${ }^{(1)}$.

Some signs and symptoms may be present immediately or several days after infusion. Immediate reactions are: burning, local discomfort and erythema, whereas later reactions include: pain, edema, induration, ulceration, vesicles, necrosis, inflammation and cellulitis ${ }^{(1)}$.

It is thought that knowledge of collateral effects and of the alternatives to control and prevent these are indispensable for the management of oncological patients. The care of patients and their families include guidance on the adverse effects related to chemotherapy and these should be based on understandable information, reinforcing the benefits of the drugs and of the alternatives for the management of the collateral effects.

This study was part of a project that evaluated the toxicity presented by women with breast cancer during chemotherapy, and aims to analyze the occurrence of dermatological toxicity provoked by drugs used in the protocol of neoadjuvant and adjuvant chemotherapy among women followed in the Mastology Outpatient Clinic of the Clinical Hospital, Faculty of Medicine of Ribeirao Preto, University of Sao Paulo (HCFMRP-USP).

The relevance of this is based on the fact that the institution has obtained good results with the Commitment to Hospital Quality and, seeking a seal of quality, is organizing the protocols of care. The results of this study helped with elements to the chemotherapy protocols.

\section{Methodology}

This study was approved by the Ethics Committee of the Clinical Hospital of the Faculty of Medicine of Ribeirao Preto, University of Sao Paulo, under number $8602 / 2007$, along with the request for waiver of the free prior informed consent form. It was carried out at the Mastology Service of HCFMRP-USP that, during the study period, preferably used the protocol of the combination of Docetaxel $50 \mathrm{mg} / \mathrm{m}^{2}$ and Epirubicin $75 \mathrm{mg} / \mathrm{m}^{2}$ for chemotherapy in women with breast cancer in neoadjuvant treatment. For adjuvant chemotherapy, Cyclophosphamide $600 \mathrm{mg} / \mathrm{m}^{2}$ and Epirubicin $60 \mathrm{mg} / \mathrm{m}^{2}$ or other schemes were used, according to medical evaluation.

For this study secondary data was used, collected from medical records of women with breast cancer, attended at the Mastology Outpatient Clinic between the years 2003 and 2006, and that underwent chemotherapy using the neoadjuvant and adjuvant regimens, already mentioned. These schemes were selected because, during the study period, they were the most frequently used. The choice of data from hospital records was based on the fact 
that the hospital records register constitutes an important means of communication between health professionals ${ }^{(5)}$ and as this was the first phase of the project it brought benefits to the design of a prospective study.

To develop the study, a list of women undergoing chemotherapy for gynecologic cancer during the study period was first obtained from the Central Chemotherapy HCFMRP-USP. In a first review of this relationship, women undergoing chemotherapy for other types of gynecological cancer, such as cancer of the cervix and ovary were excluded. Of 404 records that were reviewed 72 were selected, of women who met the inclusion criteria: age between 30 and 60 years; chemotherapy as first treatment option, use of the neoadjuvant and adjuvant chemotherapy regimens proposed for this study; chemotherapy completed by December 2006. For data collection, an instrument was designed with information on identification data, data about the diagnosis, results of the hemograms performed before each cycle of chemotherapy, dosage of chemotherapy used in neoadjuvant and adjuvant, post-chemotherapy adverse effects, data of possible hospitalization during chemotherapy and data on the surgical procedure.

\section{Results}

Records of 72 women aged between 30 and 60 years were studied, most of them being over 45 years of age. There was a predominance of white women $(83.3 \%)$ and the breast involved more frequently was the left (58\%) (Table 1 ).

Table 1 - Distribution of women undergoing chemotherapy for breast cancer by, age, color, and laterality of the tumor. Ribeirao Preto, 2008

\begin{tabular}{lc}
\hline \multicolumn{1}{c}{ Characteristic } & $\begin{array}{c}\text { Number and percentage (\%) } \\
\text { of women }\end{array}$ \\
\hline Age & $3(4.1 \%)$ \\
$30-35$ years & $12(16.6 \%)$ \\
$36-40$ years & $16(22.2 \%)$ \\
$41-45$ years & $9(12.5 \%)$ \\
$46-50$ years & $20(28 \%)$ \\
$51-55$ years & $12(16.6 \%)$ \\
$56-60$ years & \\
Color & $60(83.3 \%)$ \\
White & $2(2.7 \%)$ \\
Black & $10(14 \%)$ \\
Mixed & \\
Laterality of the tumor & $42(58 \%)$ \\
Left & $30(42 \%)$ \\
Right &
\end{tabular}

The IIIa clinical stage of breast cancer was observed most, with a frequency of $34.7 \%$ of the women, followed by IIIb with a frequency of $27.7 \%$ of them. Of the surgical treatments performed, $40 \%$ were registered as tumorectomy with axillary lymphadenectomy $(A L)$ and $34.7 \%$ as simple mastectomy with AL (Table 2).

Table 2 - Distribution of women undergoing chemotherapy for breast cancer, according to staging and type of surgery. Ribeirao Preto, 2008

\begin{tabular}{lc}
\hline \multicolumn{1}{c}{ Disease stage } & Total \\
\hline Ila & $12(16.6 \%)$ \\
Ilb & $15(21 \%)$ \\
IIla & $25(34.7 \%)$ \\
Ilb & $20(27.7 \%)$ \\
Type of surgery & \\
Tumorectomy + AL + mammary plastic & \\
surgery & $5(7 \%)$ \\
Quadrantectomy +AL & $4(5.5 \%)$ \\
Mastectomy + AL + mammary reconstruction & $3(4.1 \%)$ \\
Margin expansion + AL & $1(1.4 \%)$ \\
Halsted mastectomy + LA & $1(1.4 \%)$ \\
No surgery carried out & $2(2.7 \%)$ \\
\hline
\end{tabular}

During the chemotherapy, a total of 558 cycles were performed, with description of various complications that interfered in the duration of treatment. It was not possible, during the review of medical records, to identify the degree of toxicity of the non-hematologic adverse events, because the adverse events reported in the medical or nursing records were merely cited, without description, making it difficult to assess the degree of toxicity presented.

The records presented 77 registrations of adverse events during the period of neoadjuvant therapy, 18 being of hematologic toxicity and 59 of non-hematological toxicity. In the adjuvant chemotherapy 75 adverse events were recorded, 50 being of non-hematological toxicity and 25 of hematological toxicity (Table 3 ).

Among the non-hematologic toxicities, there were a total of 37 dermatological registrations, darkened venous pathway being prevalent in the neoadjuvant and adjuvant periods, with $23.7 \%$ and $12 \%$ respectively. The occurrence of hardened veins was described in 10 records, divided equally between the neoadjuvant and adjuvant periods (Table 3 ).

Another complication observed was extravasation during the administration of chemotherapy, which occurred in 17 (23.6\%) women, however, there were 20 records of extravasation, of which nine were in the neoadjuvant and 11 in the adjuvant phase. This fact shows that some women had more than one occurrence of extravasation in different cycles, or even in the same cycle (Table 4). 
Table 3 - Frequency distribution of non-hematologic toxicity in women undergoing chemotherapy, Ribeirao Preto, $2008(\mathrm{~N}=109)$

\begin{tabular}{lccc}
\hline $\begin{array}{c}\text { Non-hematologic } \\
\text { toxicity }\end{array}$ & Neoadjuvant & Adjuvant & Total \\
\hline $\begin{array}{l}\text { Dermatological } \\
\text { Darkened venous }\end{array}$ & Total $=26$ & Total $=11$ & $37(34 \%)$ \\
pathway & $14(23.7 \%)$ & $6(12 \%)$ & $20(18.3 \%)$ \\
Indurated veins & $10(16.9 \%)$ & $5(10 \%)$ & $15(13.8 \%)$ \\
Others & $2(3.3 \%)$ & - & $2(1.8 \%)$ \\
Others & Total $=33$ & Total $=39$ & $72(66 \%)$ \\
Total & 59 & 50 & 109 \\
\hline
\end{tabular}

Table 4 - Distribution of women undergoing chemotherapy for breast cancer, according to occurrence of extravasation. Ribeirao Preto, 2008

\begin{tabular}{lccc}
\hline \multicolumn{1}{c}{ Extravasation } & Neoadjuvant & Adjuvant & Total \\
\hline Number of events & 09 & 11 & 20 \\
Drug & & & \\
$\quad$ Epirubicin & 08 & 08 & 16 \\
Docetaxel & 01 & - & 01 \\
Cyclophosphamide & - & 03 & 03 \\
Cycles & & & \\
1 & 04 & 02 & 06 \\
2 & 02 & 01 & 03 \\
3 & 02 & 02 & 04 \\
4 & 01 & 06 & 07 \\
\hline
\end{tabular}

The follow-up and consequences of these extravasations appear poorly reported, and there were few reports recorded in the medical records, neither by the nursing staff of the Chemotherapy Center, the Mastology Outpatient Clinic or the ward in which the women with breast cancer were hospitalized.

Of the 20 registrations of extravasation, it was observed that nine $(45 \%)$ occurred during the neoadjuvant therapy phase and the consequences registered in medical records were: two (22.2\%) reports of indurated lesion in the area, one $(11.1 \%)$ reference of not presenting alterations, one $(11.1 \%)$ of fibrosis in the area and one $(11.1 \%)$ report of pain, hyperemia and indurated lesion at the site, while in four (44.4\%) instances there is no record of the follow up action. In the adjuvant phase, of the 11 extravasations registered, two $(18 \%)$ reports of indurated lesion in the area were observed and one (9.1\%) of fibrosis and local pain, which was referred to physiotherapy to implement resources that improve pain and movement of the affected hand, in eight $(72.7 \%)$ instances no record of the action were observed.

Table 5 shows the actions related to the occurrence of extravasation. It was observed that, in spite of the protocol defined by the institution, the registrations vary regarding application with the occurrence of extravasation of the same drug, as shown below.

Table 5 - Distribution of women undergoing chemotherapy for breast cancer, according to application of extravasation protocol. Ribeirao Preto, 2008

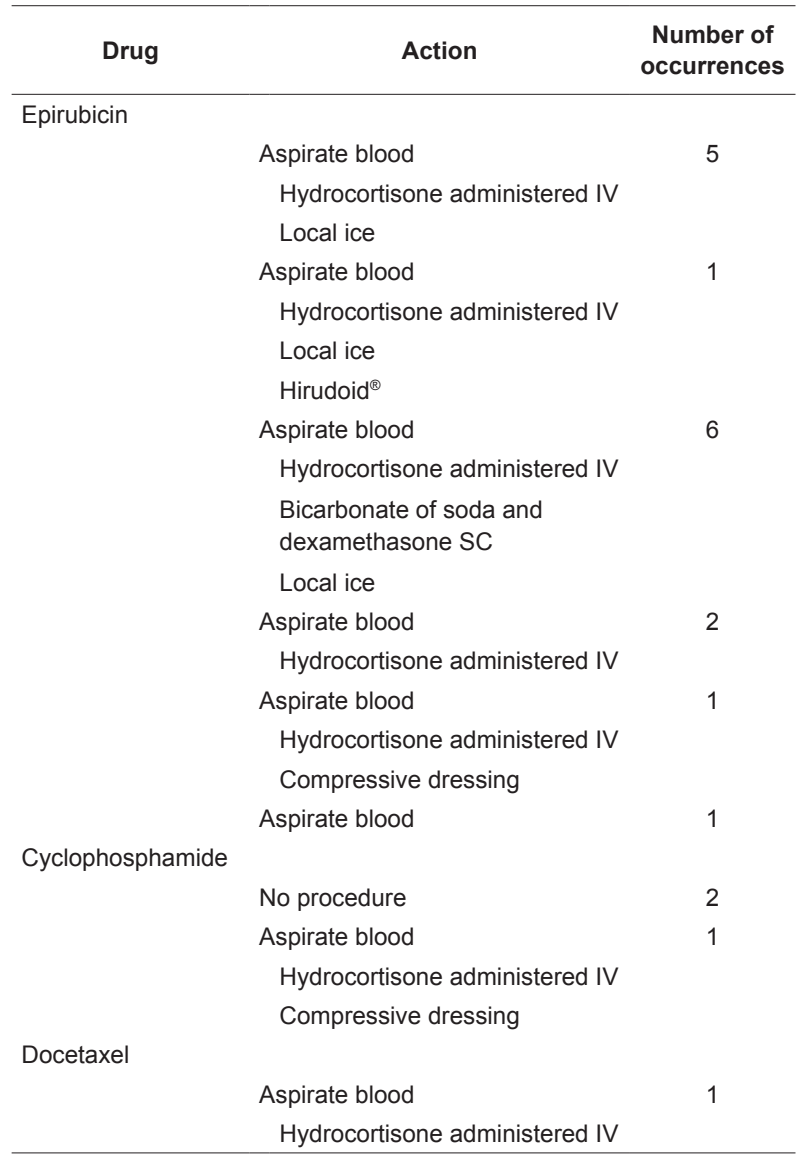

\section{Discussion}

Chemotherapy takes prominence in the management of tumors, and has improved the prognosis of many neoplasms, but the majority of chemotherapeutic agents can cause dermatologic toxicity. Vesicant drugs have been used routinely for decades, and there is a gap in informed evidence and in their control. When an extravasation occurs or is suspected, the infusion is stopped and the affected area should be inspected and the treatment given with the correct antidote to the drug ${ }^{(3-4,6)}$.

The occurrence of extravasation of chemotherapy in this study $(23.6 \%)$ was higher than that found in the literature, which ranges from 0.01 to $6.5 \%{ }^{(3)}$, but there are few studies that report on the occurrence of extravasation. Because it is an event that can lead 
to significant morbidity, this high incidence points to the need for adequate training of professionals who administer chemotherapy in the institution studied, who value the recording of most of these occurrences ${ }^{(1)}$.

Preventive measures are strongly advocated in the scientific literature, such as observation, cooperation on the part of patients and recognition of the effects of drugs by the team of professionals. Other preventive measures, such as avoiding punctures near the joints and bony prominences; skill, experience and scientific technical expertise of the professional; puncture with minimal trauma using small caliber catheters; testing of the vein initially with isotonic solution; catheter fixation with visualization of the venous pathway; valorization of patients' complaints about stinging and burning; avoidance of fragile veins (dorsal hand antecubital fossa and feet); infusing 50 to $10 \mathrm{ml}$ of saline between one drug and another, are complemented with the recommendation of recording all actions performed by the nurse $e^{(4,7-8)}$. However, in this study it was not possible to identify preventive measures established by the nursing team in their records, except for the complaints of women during infusion.

A lack of consensus for the management of extravasation was also observed in the scientific literature, as several antidotes for the same drug were indicated as was the use or non-use of corticosteroids. Although there is no consensus about localized drug use, the local application of ice for all drugs, except for the vinca alkaloids and oxaliplatin, when heat should be used, is an empirical measure used for many years, but with no evidence of benefits ${ }^{(7-9)}$. The protocol used in the service where this study was conducted is consistent with that suggested in the international literature, except for the use of sodium bicarbonate, which has not been recommended for its vesicant effect when given outside the vessel(8-9).

During the review of medical records, it was observed that nursing professionals value the recording of the occurrence or suspicion of extravasation. However, monitoring these complications was poorly reported by nursing teams that assist women with breast cancer (Chemotherapy Center, Outpatient Clinic and Ward). COFEN Resolution No 210/1998(10) states that it is duty of the nurse "to plan, organize, supervise, execute and evaluate all activities of Nursing, for clients undergoing antineoplastic chemotherapy, categorizing it as a service of high complexity, grounded in Nursing care methodology". Thus, the registration of all interventions performed by nurses during the infusion of chemotherapy is the duty of nurses and after the occurrence of extravasation, registration and monitoring are of fundamental importance in the quality of care provided to oncological patients.

Proper documentation of extravasation demonstrates the practice of nursing care. The inverse of this may be interpreted as a failure in this care. The recording should be made for all steps of the infusion of chemotherapeutic agents, from the venipuncture until removal, including the infusion of serums and other medications $^{(11)}$.

Documentation must be performed when there is suspicion of extravasation or if it is confirmed and must cover all actions taken by the nurse, as well as the responses to these interventions ${ }^{(11)}$.

The follow-up of the lesions also must be registered with a clear and detailed description of the affected area, and the patient's response to treatment. For better documentation and evaluation of actions, the nurse can make use of the photographic record of the area where the extravasation occurred or was suspected ${ }^{(11-12)}$.

\section{Conclusion}

A high number of extravasation records in the service were observed, which reveals how nurses, working in the field, value and are attentive to the occurrence or suspicion of extravasation. However, it was observed that the registering of follow-up was not as valued by these professionals. Issues such as continuing education for them are extremely important, so that it becomes more evident that the nursing work performed with these patients is of fundamental importance.

Moreover, these nurses should be encouraged to carry out scientific research to identify more effective strategies for prevention and intervention of extravasation, improving the quality of life of patients and valorizing the work of nurses.

\section{References}

1. Bonassa EMA, Santana TR. Enfermagem em Terapêutica Oncológica. 3a ed. Rio de Janeiro (RJ): Atheneu; 2005.

2. National Cancer Institute. Common toxicity criteria, Version 2.0. [online]1999., [acesso em: 20 junho 2007] Disponível http://safetyprofiler-ctep.nci.nih.gov/CTC/CTC.aspx.
3. Schulmeister L. Extravasation management. Semin Oncol Nurs. 2007; 23(3):184-90.

4. Dougherty L. IV therapy: recognizing the differences between infiltration and extravasation. Br J Nurs. 2008; 17(4):896-901. 
5. Pereira, MG. Morbidade. In: Epidemiologia: Teoria e Prática. $3^{a}$ ed. Rio de Janeiro (RJ): Guanabara Koogan; 2002.

6. Wickam R, Engelking C, Sauerland C, Corbi D. Vesicant extravasation part II: Evidence-based management and continuing controversies. Oncol Nurs Forum. 2006; 33 (6):1143-50.

7. Schulmeister L. Managing vesicant extravasations. Oncologist $2008 ; 13: 284-8$.

8. Goolsby TV, Lombardo FA. Extravasation of chemotherapeutic agents: prevention and treatment. Semin Oncol. 2006; 33(1):139-43
9. Ener RA, Meglathery SB, Styler M. Extravasation os systemic hemato-oncological therapies. Ann Oncol. 2004; 15:858-62.

10. Conselho Regional de Enfermagem, SP (BR). Resolução COFEN No 210/1998. Dispõe sobre a atuação dos profissionais de Enfermagem que trabalham com quimioterápico antineoplásicos. Brasília; maio 2006. Disponível em: http://inter.coren-sp.gov. $\mathrm{br} /$ node/3951

11. Saurland C, Engelking C, Wickham R, Corbi D. Vesicant Extravasation Part I: Mechanisms, Pathogenesis, and Nursing Care to Reduce Risk. Oncol Nurs Forum. 2006; 33(6):1134-41. 12. Boyle DM, Engelkin C. Vesicant extravasation: myths and realities. Oncol Nurs Forum. 1995; 22:57-67.

Received: May. 27th 2009

Accepted: May. $3^{\text {rd }} 2010$ 